\title{
Arid Lands of the Southwest
}

When thinking about plants and animals that inhabit hot arid lands of the southwestern U.S., fish are easily overlooked by most people. However, these desert lands often contain isolated springs or cienegas (a Spanish term referring to permanently saturated "seep wetlands") and streams supporting native fishes that occur no where else in the world. These aquatic remnants from the last Ice Age have survived for thousands of years due to an amazing ability to tolerate harsh environmental conditions, especially extremely high water temperatures, high salinities, and unpredictable water flows.

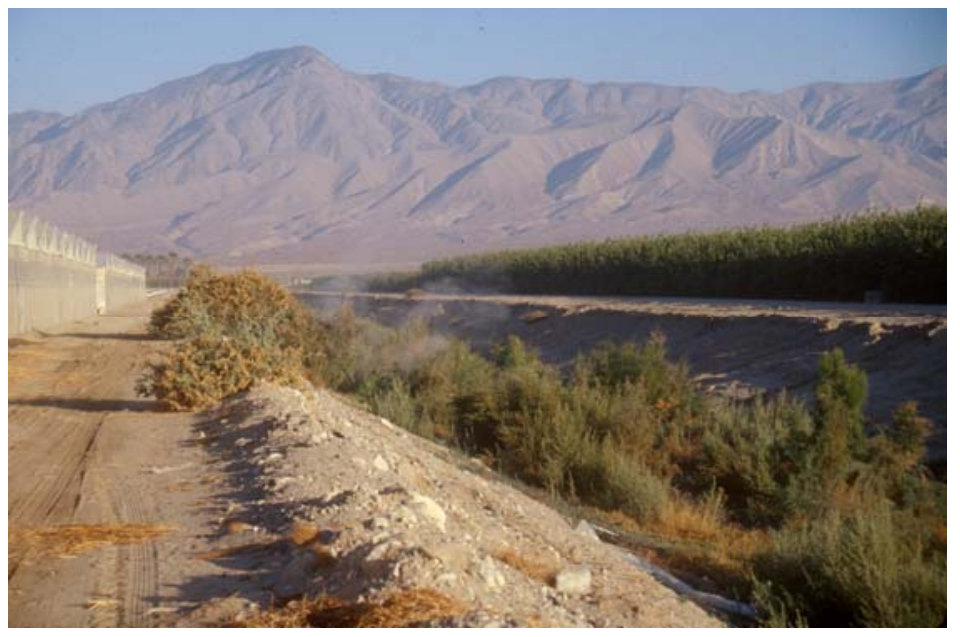

Agricultural drain in the Salton Sea Basin.
Fish communities within a desert spring or stream often consist of only a few genetically unique species such as desert pupfish (Cyprinodon macularius), Moapa dace (Moapa coriacea), and cui-ui (Chasmistes cujus) with adaptations particularly suited for their natural environments. Today, these fishes are in jeopardy mainly due to several anthopogenic effects. Perhaps the greatest threat is man's constant need for water and his manipulation of the natural environment via diversions of surface water and the mining of groundwater. Without a reliable water source, many native fishes in arid lands are in constant danger of perishing.

Another important anthropogenic factor is the introduction of nonnative fishes into these simple ecosystems.

Through still poorly understood ecological interactions, nonnative species often replace the unique native species. Desert fishes may be especially vulnerable to invasions of nonnative fishes because they generally evolved under conditions of little or no competitors and predators.

A third anthropogenic effect is contamination by metals, pesticides, and other chemical compounds that cause outright lethality or sublethal effects, such as reproductive impairment, reduced growth, increased vulnerability to environmental stresses and disease, and behavioral changes. Because arid ecosystems are already very fragile, any of these anthropogenic disturbances can lead to extinction of native fish species. To avoid irreversible ecological catastrophes, people must be made aware of how their actions can adversely affect native fishes and other aquatic biota in arid lands.

\section{Desert Pupfish are Losing Ground}

The desert pupfish is one of a small handful of native fishes

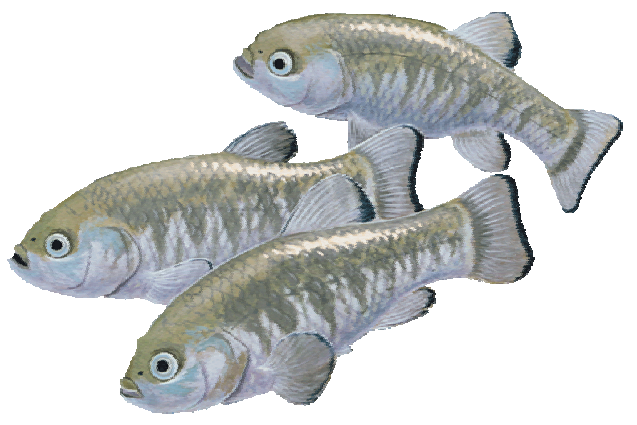




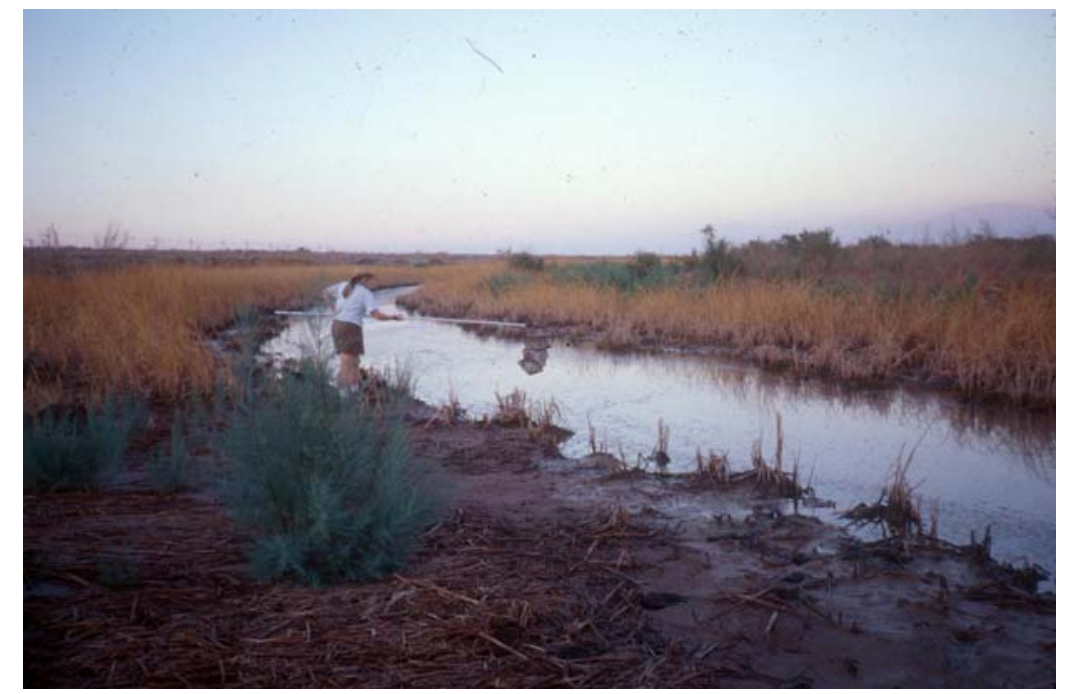

Desert pupfish collected from an agricultural drain adjacent to the Salton Sea. These fish are measured and weighed, then released at the collection site.

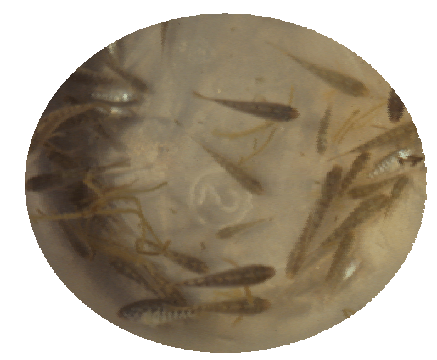

that still persist in the arid Southwest. Although previously widespread throughout the Sonoran and Mojave deserts of southern California, southern Arizona, and northwest Mexico, this fish is now confined mostly to artificial refugia and a few small streams. Perhaps the largest population occurs in agricultural drains that flow into the Salton Sea. Plummeting numbers of pupfish throughout its historical range led to the listing of this species for federal protection as endangered in 1986.
Recent studies by the USGS Western Fisheries Research Center (WFRC) have shown that predation by nonnative fishes may have a major influence on abundance and distribution of pupfish in and around the Salton Sea. As a result, resource managers have recommended eliminating nonnative species to preserve remaining pupfish populations. Today, natural habitats for pupfish include San Sebastian Marsh and San Felipe Creek on the southwestern edge of the
Salton Sea, and Salt Creek on the northern shore.

Pupfish can tolerate hostile environments with excessively high temperatures, high salinities, and low dissolved oxygen, which enable them to survive in environments hostile to less hardy nonnative species. They generally do not live beyond 2 years of age. Breeding males are territorial and acquire an intense blue coloration to attract mates.

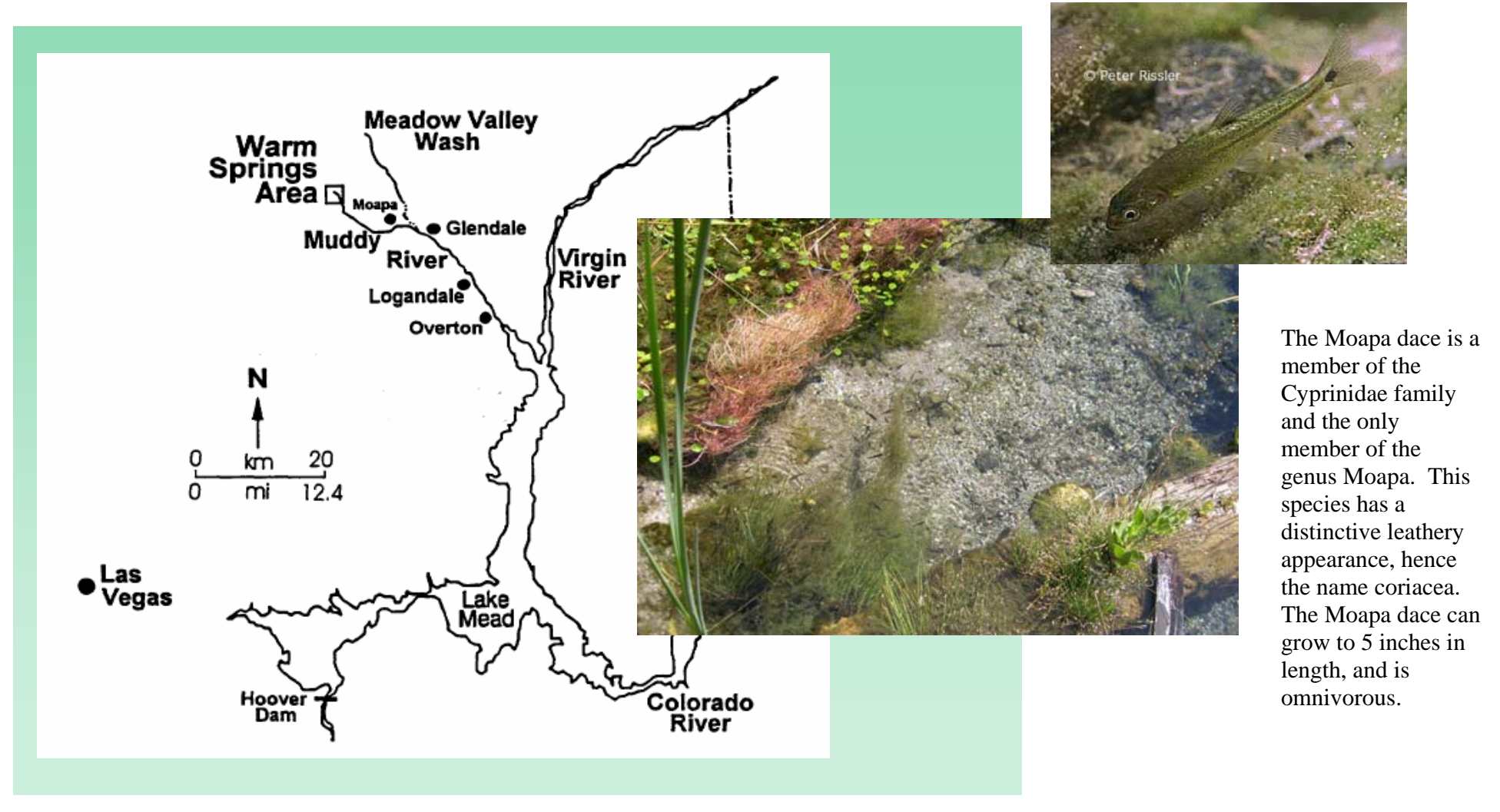


Unique Warm Water Fish Get Help

The Moapa dace is an endangered fish species that occurs only near the origin of the Muddy River which originates from warm water springs, about 50 miles northeast of Las Vegas. These small fish live in water with temperatures ranging from 26 to $32^{\circ} \mathrm{C}\left[79^{\circ} \mathrm{F}\right.$ to $\left.90^{\circ} \mathrm{F}\right]$ - such fish are called "thermal endemic" species, meaning that they require warm water to survive.

The persistence of the Moapa dace has recently been jeopardized. First, the headwaters of the Muddy River were invaded by nonnative blue tilapia (Oreochromis aureus), which are known herbivores but switch to eating dace once all the aquatic vegetation was gone, and eliminated Moapa dace from $90 \%$ of its former range. Secondly, spring flow in $10 \%$ of the habitat not invaded by blue tilapia is declining due to pumping of nearby groundwater (the carbonated aquifer), the source of the spring flow. Reduction in spring flow is expected to lessen habitat quantity and quality through loss of water volume that reduces the extent of thermal habitat on which the fish is dependent.

Biologists from the WFRC were contracted by the U.S. Fish and Wildlife Service to collect pertinent data and develop a model that predicts the persistence of Moapa dace under various changing environmental conditions. This new generation model, along with field and laboratory data, will include movement, growth, and respiration of the fish, and will be a useful tool to manage and protect Moapa dace in its changing environment.

\section{Saving an Old Fish in the Desert}

The cui-ui (pronounced "Kweewee") is a sucker that occurs only in Pyramid Lake, Nevada. It reaches lengths in excess of 30 inches and weights up to 10 pounds. Cui-ui are a favorite food fish of the Northern Paiute Indians and have special cultural significance to the tribe.

Cui-ui are obligatory lake dwellers that spawn in the Truckee River, Pyramid Lake's only perennial tributary. Each spring, adults migrate to the south end of Pyramid Lake and await environmental cues to migrate into the Truckee River to spawn.

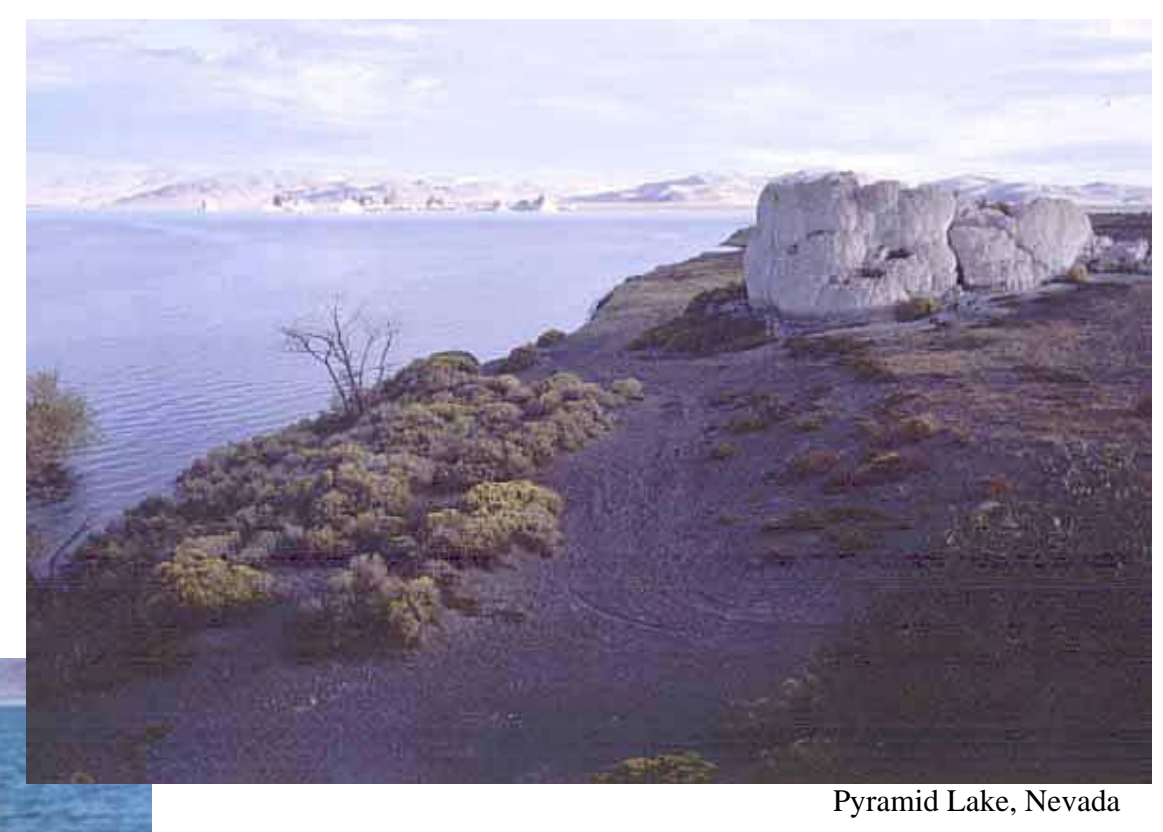

In the $20^{\text {th }}$ century their river spawning migration was blocked by agricultural water diversions, the largest of which is the transbasinal canal (Truckee Canal) that diverts water to the Carson River system and thence to the Carson Valley. Completed in 1906 as part of this Nation's first Bureau of Reclamation Project (The Newlands Project), the diversion was largely responsible for causing Pyramid Lake to subside roughly 80 feet, creating a shallow impassable delta at the mouth of the Truckee River. 
These changes caused the Pyramid Lake strain of Lahontan cutthroat trout (Oncorhyncus clarki) to become extinct by the early 1940s. However, the cuiui's incredible longevity $(>50$ years) allowed it to persist until high water years enabled it to traverse the delta. Even at that, spawning was infrequent enough to cause the population to decline. In 1967, this trout was listed as an endangered species.

In an attempt to revitalize the Pyramid Lake fishery the Marble Bluff Fish Passage Facility was completed in 1976 to serve as a bypass around the Truckee River Delta. The facility has been improved over the years and is now very successful in passing cui-ui. More recently, changes in Truckee River operations and the Truckee-Carson-Pyramid Lake Water Rights Settlement Act of 1990 have served to enhance Truckee River flows into Pyramid Lake.

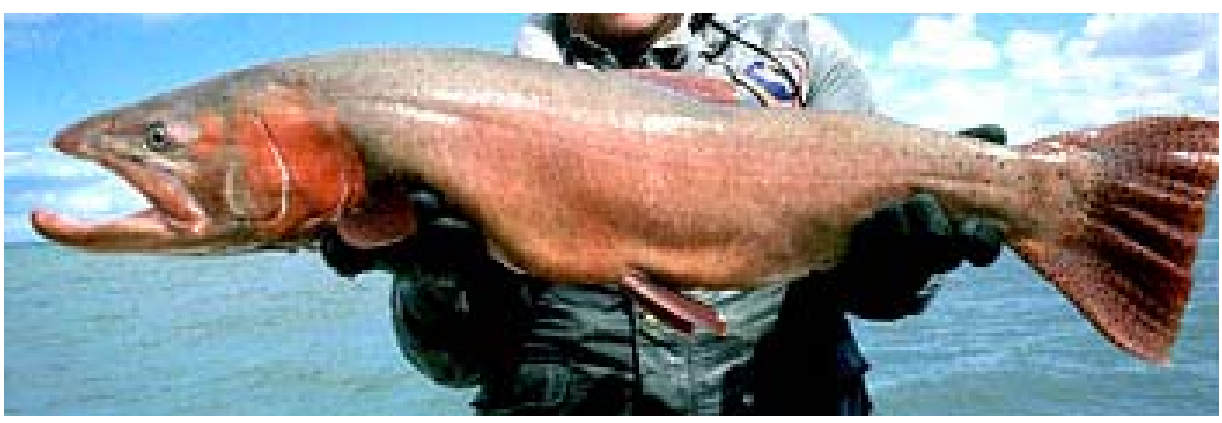

Lahontan cutthroat trout (Oncorhynchus clarki)

Whether construction of the Marble Bluff Fish Passage Facility and the additional stream flow are sufficient to save the cui-ui has been in question.

Biologists from the WFRC developed a cui-ui population viability model, which is sensitive to spawning frequency. Scientists are currently preparing support papers on cui-ui life history traits and survival to be used in the model. The model is intended to insure the persistence of cui-ui through wise use of limited water resources that are necessary for cui-ui spawning.

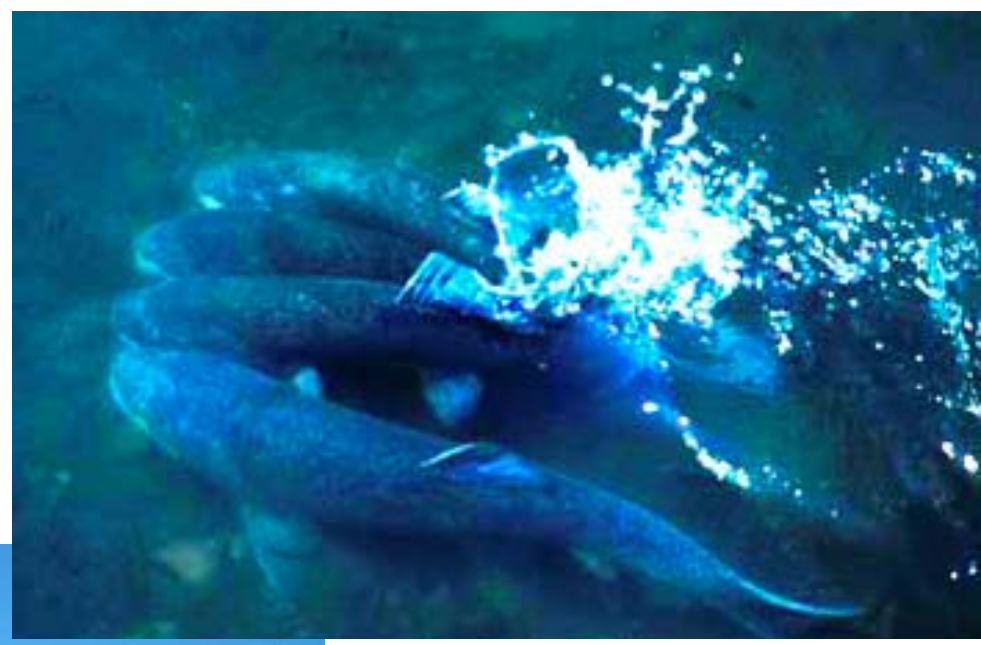

Cui-ui spawning in the Truckee River

\section{For additional information, please} contact:

Lyman Thorsteinson, Center Director U.S. Geological Survey Western Fisheries Research Center 6505 NE $65^{\text {th }}$ Street, Seattle, WA 98115

(206-526-6282 FAX (206) 526-6654 http://wfrc.usgs.gov 